日植病報 $40: 6-13(1974)$

Ann. Phytopath. Soc. Japan 40:6-13 (1974)

\title{
Distribution of Xanthomonas citri Strain in Relation to the Sensitivity to Phages $\mathrm{CP}_{1}$ and $\mathrm{CP}_{2}$
}

\author{
Takushi OватA* \\ 小烟挀志*：日本に分布する Xanthomonas citri の \\ $\mathrm{CP}_{1}$ および $\mathrm{CP}_{2}$ ファージ感受性
}

\begin{abstract}
A large number of Xanthomonas citri isolates representing five major citrus regions (excluding quarantined canker-free export areas involved) were tested for their susceptibility to Wakimoto's phages $\mathrm{CP}_{1}$ and $\mathrm{CP}_{2}$. Throughout the regions, $\mathrm{CP}_{2}$-sensitive strains were predominantly widespread in Satsuma orange plantings while in plantings of other varieties, both $\mathrm{CP}_{1}$-sensitive and $\mathrm{CP}_{2}$-sensitive strains occur in varying ratios. Geographical pattern of the strain distribution was not distinct. Two different strains can occur in mixture on one leaf of a tree but one single lesion is usually composed of one homologous strain.

Of a sum total of 1256 isolates collected in wide range surveys, only 17 (1.4 percent) were resistant to both $\mathrm{CP}_{1}$ and $\mathrm{CP}_{2}$. None out of 2514 isolates examined in intensive spot surveys was resistant to both phages. No indication was recognized for the presence in clusters of immune strains in any part of the covered regions. Intraspecific lysis spectrum of $\mathrm{CP}_{1}$ plus $\mathrm{CP}_{2}$ is comprehensive enough to include virtually all $X$. citri strains which occur in Japanese citrus export regions.
\end{abstract}

(Received April 14, 1973)

In Japan, Wakimoto's phages $\mathrm{CP}_{1}$ and $\mathrm{CP}_{2}$ have been well known as two representative virulent phages which specifically attack citrus canker bacteria, Xanthomonas citri (HASSE) DowsON ${ }^{6)}$. Host specificity of these phages is generally well defined in that majority of $\mathrm{CP}_{1}$-sensitive $X$. citri strains are resistant to $\mathrm{CP}_{2}$ while most of $\mathrm{CP}_{2}$-sensitive strains are conversely resistant to $\mathrm{CP}_{1}$. To conform with the United States plant quarantine requirements which accompanied her revision of Quarantine No. 26 in 1967, Japan has since 1968 implemented, among manifold phytosanitary actions, a phage test procedure as a final step to ensure freedom of export fruits from the citrus canker organisms. Phage $\mathrm{CP}_{1}$ and $\mathrm{CP}_{2}$ were adopted in this test on the basis of Wakimoto's finding that nearly all $X$. citri strains he collected from scattered regions in Japan were lysed by either of these two phages $^{2,6)}$. In view of the limited scope of his studies and particularly because the strains he did examine from Satsuma orange sources (our leading export variety) were quite small in numbers, an open question has been left whether the use of only these two phages is warranted or not. Hence, the author has launched upon a series of extensive surveys on the distribution of both sensitive and resistant strains of $X$. citri in major citrus regions that are concerned with Satsuma orange toward the United States. Results accumulated up to date are presented here.

* Research Division, Yokohama Plant Protection Station, Yokohama, Japan. Present Address, Nagoya Plant Protection Station, Nagoya, Japan. 横浜植物防疫所, 現在名古屋植物防疫所 


\section{Materials and Methods}

Collection of $\boldsymbol{X}$. citri isolates Wide range surveys: These surveys were planned primarily to elucidate geographical patterns of distribution, if present, of $X$. citri strains and to assess the extent of occurrence of resistant strains in major citrus regions. Cankered leaves of citrus trees were sampled extensively throughout Shizuoka, Wakayama, Hiroshima, Tokushima and Ehime prefectures during the years 1968-1971. In picking the cankered leaves, preference was given to the variety Satsuma orange. Where no canker specimens were available on this variety, other varieties were also sampled. These include Natsudaidai orange, Hassaku orange, Navel orange, lemon, Iyokan orange, Sudachi orange, trifoliate orange, Trovita orange, Ponkan orange and Junos orange. For the isolation of pathogenic bacteria, several canker lesions from each sample were ground in sterile water and the homogenate was cultured with potato semi-synthetic agar (PSA) medium ${ }^{6)}$ by conventional dilution plating. One to several single colonies were isolated onto PSA slants and used for phage sensitivity tests.

Intensive spot surveys: These surveys were initiated in 1972 to clarify the mode of localization of $X$. citri strains in a few selected orchards. Three orchards were selected in Ehime and Shizuoka prefectures, respectively, and a minute sampling was made in the manner illustrated in Figure 1. In each orchard, three to four spots of heavily infected trees were chosen. A minimum of three trees adjacent to each other were selected in each spot and several leaves with plural canker lesions were plucked separately from three different sides of each tree top.

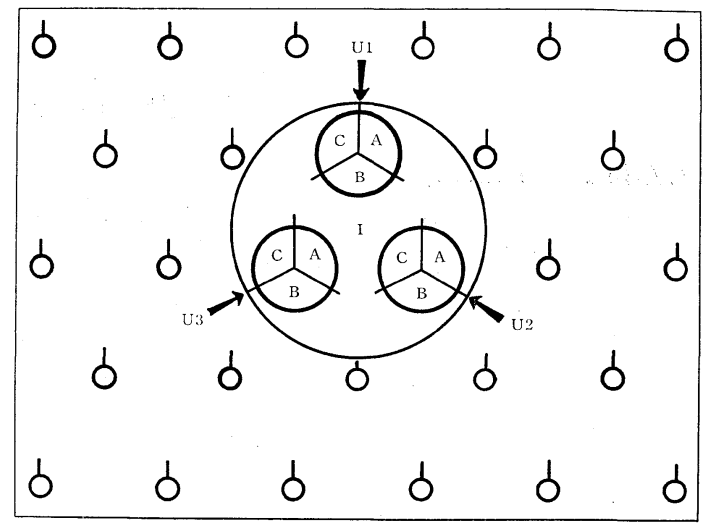

Fig. 1. Diagram showing method of sampling cankered leaves in intensive spot surveys.

I: Spot number.

U1, U2, U3: Tree numbers of Satsuma orange. A, B, C : Part of tree top where samples were taken.

For the isolation of bacteria, three lesions were punched out of one leaf and each single lesion was cultured by the dilution technique. As far as the bacterial recovery allowed, a minimum of five single colonies were collected from one lesion culture and subjected to the subsequent phage sensitivity tests.

Phage preparations Phages $\mathrm{CP}_{1}$ and $\mathrm{CP}_{2}$ and the respective host bacteria $\mathrm{N} 6101$ and $\mathrm{N} 6119$ were provided by Dr. S. Wakimoto. These phages were reisolated by a series of single plaque transfers on PSA plates. For the enrichment of phages, several new plates of confluent lysis were flooded with $20 \mathrm{ml}$ per plate of heavy suspensions $\left(10^{9} \mathrm{cell} / \mathrm{s} / \mathrm{ml}\right)$ of host bacteria at the logarithmic growth phase. After an overnight incubation at $25 \mathrm{C}$, the phage-bacteria mixture was collected, clarified by centrifugation and then treated with chloroform to inactivate temperate phages that might have been liberated during the propagation process. Average titres reached by this procedure were $10^{9}-10^{10}$ plaque forming units per $\mathrm{ml}$. The phage preparations thus obtained were stored by freeze-drying and used at desired dilutions as needed.

Phage sensitivity tests Phage sensitivity of $X$. citri isolates was determined as follows; The bacterial cultures were refreshed on PSA slants for $18-24$ hours at $25 \mathrm{C}$ and suspended in sterle 
distilled water at the concentration of $10^{8}$ cells per $\mathrm{ml}$. Phages were diluted in PS medium at a titre of $10^{3}-10^{4}$ plaque forming units per $\mathrm{ml}$. A mixture of $2 \mathrm{ml}$ of the bacterial inoculum and $0.1 \mathrm{ml}$ of the phage dilution was plated with 3 to $5 \mathrm{ml}$ of PSA medium and incubated at 25C for plaque formation. Prior to this procedure, a qualitative test had been made by placing one droplet of high titre phage suspension on the agar layer seeded with each isolate to be tested. For those isolates that remained negative in these tests, plaque formation was tried by the double layer technique ${ }^{1)}$ by using different doses of the bacterial inocula ( $10^{7}$ to $10^{8}$ cells per plate). Those isolates which gave no lytic reaction through a series of five such tests were classified as resistant strains. During the initial stage of this investigation, the author has become increasingly aware that the phage sensitivity of $X$. citri cultures undergoes frequent degeneration in the course of preservation by transfers. In order to reflect the sensitivity in vivo of $X$. citri strains as is possessed in nature, all isolates were tested as soon as possible after the isolation i.e. within a maximum period of two months and of two serial transfers.

\section{Results and Discussions}

Wide range surveys Distribution patterns of $X$. citri strains: Results obtained from the year 1968 through 1971 are summarized in Table 1 . As a whole, a very contrasting pattern in the distribution of $X$. citri strains can be noted in that a great majority of the isolates from Satsuma orange sources are $\mathrm{CP}_{2}$-sensitive whereas in those from other varieties, both $\mathrm{CP}_{1}$-sensitive and $\mathrm{CP}_{2}$-sensitive strains appear in varying proportions depending upon the difference in localities or orchards. Such pattern is best exemplified in the data from Shizuoka and Ehime prefectures where most exhaustive samplings were made. Of a total of 390 isolates originated from Satsuma orange in Shizuoka, 365 (93.6 percent) were $\mathrm{CP}_{2}$-sensitive while the percentage occurrence of both strains in 93 isolates from other varieties was approximately equal. Likewise, Satsuma orange in Ehime yielded 114 (90.5 percent) $\mathrm{CP}_{2}$-sensitive isolates out of 126 isolates examined. Of 37 isolates optained from non-Satsuma oranges here, 26 (70.3 percent) were found to be $\mathrm{CP}_{1}$-sensitive strains. In Tokushima, $\mathrm{CP}_{2}$-sensitive strains were prevalent in both Satsuma and other varieties. A high incidence of $\mathrm{CP}_{2}$-sensitive strains in non-Satsuma oranges in this district may well be due to the deliberate sampling of the source trees from the direct proximity to the similarly sampled Satsuma trees as was really the case here. An apparent reverse pattern was encountered only in Hiroshima prefecture where $\mathrm{CP}_{1}$-sensitive strains appeared extensively in both Satsuma and non-Satsuma varieties. Here too, however, of a total of 40 mono-plantings of Satsuma orange sampled, 26 (65 percent) were exclusively infected with $\mathrm{CP}_{2}$-sensitive strains, followed by 8 (20 percent) with $\mathrm{CP}_{1}$-sensitive strains and 6 (15 percent) with both strains, thus pinpointing to the general pattern of the dominance of $\mathrm{CP}_{2}$-sensitive strains in Satsuma orange. In contrast, of a total of 45 mixed plantings of Satsuma and other varieties, 35 (78 percent) were occupied with $\mathrm{CP}_{1}$-sensitive strains and only 6 (13 percent) with $\mathrm{CP}_{2}$-sensitive strains. Seen geographically, both strains occur more or less evenly in western islets of this district while $\mathrm{CP}_{1}$-sensitive strains are dominant in central isolets. $\mathrm{CP}_{2}$-sensitive strains are widespread in eastern areas where extensive Satsuma plantings have been established in recent years. Hiroshima has a long history of the cultivation of Hassaku, Navel, lemon and other varieties. Finely intermingled with Satsuma orange plantings, tiny plantings of these varieties still exist at every section of the citrus areas of this prefecture. The prevalence as a whole of $\mathrm{CP}_{1}$-sensitive strains here may be due to the buildup of those strains that have originated and spread from these canker-susceptible varieties

Thus, the basic patterns of geographical distribution of $X$. citri strains can be summarized as follows; In Hiroshima and the Setouchi isoland section of Ehime, both strains are present in Satsuma 
orange in good balance with each other whereas, in other varieties, $\mathrm{CP}_{1}$-sensitive strains are by far predominant. In other regions including Shizuoka, Wakayama, Tokushima and the coastal area of Ehime, nearly 90 percent of the strains which occur on Satsuma orange are $\mathrm{CP}_{2}$-sensitive while in other varieties, both strains show variable degrees of occurrence depending upon particular localities and plantings.

Table 1. Sensitivity to phage $\mathrm{CP}_{1}$ and $\mathrm{CP}_{2}$ of Xanthomonas citri isolates collected throughout five major citrus export regions in Japan during the years 1968-1971

\begin{tabular}{|c|c|c|c|c|c|c|c|c|c|}
\hline \multirow[t]{2}{*}{ Prefecture } & \multirow{2}{*}{$\begin{array}{l}\text { No. of } \\
\text { localities } \\
\text { covered }^{a)}\end{array}$} & \multirow{2}{*}{$\begin{array}{l}\text { Source } \\
\text { trees }\end{array}$} & \multirow{2}{*}{$\begin{array}{l}\text { No. of } \\
\text { isolates }\end{array}$} & \multicolumn{2}{|c|}{$\begin{array}{c}\text { Sensitive } \\
\text { to } \mathrm{CP}_{1}\end{array}$} & \multicolumn{2}{|c|}{$\begin{array}{l}\text { Sensitive } \\
\text { to } \mathrm{CP}_{2}\end{array}$} & \multicolumn{2}{|c|}{$\begin{array}{l}\text { Resistant to } \\
\mathrm{CP}_{1} \& \mathrm{CP}_{2}\end{array}$} \\
\hline & & & & No. & Percent & No. & Percent & No. & Percent \\
\hline \multirow[t]{3}{*}{ Shizuoka } & \multirow{3}{*}{$\begin{array}{l}108 \\
(29)\end{array}$} & Satsuma & 390 & 19 & 4.9 & 365 & 93.6 & 6 & 1.5 \\
\hline & & \multirow{2}{*}{$\begin{array}{l}\text { Other var. } \\
\text { Total }\end{array}$} & 93 & 50 & 53.8 & 42 & 45.2 & 1 & 1.1 \\
\hline & & & 483 & 69 & 14.3 & 407 & 84.3 & 7 & 1.4 \\
\hline Wakayama & $\begin{array}{r}25 \\
(11)\end{array}$ & Satsuma & 27 & 3 & 11.1 & 23 & 85.2 & 1 & 3.7 \\
\hline \multirow[t]{3}{*}{ Hiroshima } & \multirow{3}{*}{$\begin{array}{r}70 \\
(19)\end{array}$} & Satsuma & 225 & 120 & 53.3 & 100 & 44.4 & 5 & 2.2 \\
\hline & & Other var. & 150 & 135 & 90.0 & 15 & 10.0 & 0 & 0 \\
\hline & & Total & 375 & 255 & 68.0 & 115 & 30.7 & 5 & 1.3 \\
\hline \multirow[t]{3}{*}{ Tokushima } & \multirow{3}{*}{$\begin{array}{r}39 \\
(16)\end{array}$} & Satsuma & 185 & 8 & 4.3 & 176 & 95.1 & 1 & 0.5 \\
\hline & & Other var. & 23 & 7 & 30.4 & 16 & 69.6 & 0 & 0 \\
\hline & & Total & 208 & 15 & 7.2 & 192 & 92.3 & 1 & 0.5 \\
\hline \multirow[t]{3}{*}{ Ehime } & \multirow{3}{*}{$\begin{array}{r}84 \\
(39)\end{array}$} & Satsuma & 126 & 12 & 9.5 & 114 & 90.5 & 0 & 0 \\
\hline & & Other var. & 37 & 26 & 70.3 & 8 & 21.6 & 3 & 8.1 \\
\hline & & Total & 163 & 38 & 23.3 & 122 & 74.8 & 3 & 1.8 \\
\hline \multirow[t]{3}{*}{ Grand Total } & \multirow{3}{*}{$\begin{array}{r}326 \\
(114)\end{array}$} & Satsuma & 953 & 162 & 17.0 & 778 & 81.6 & 13 & 1.4 \\
\hline & & Other var. & 303 & 218 & 71.9 & 81 & 26.7 & 4 & 1.3 \\
\hline & & Total & 1256 & 380 & 30.3 & 859 & 68.4 & 17 & 1.4 \\
\hline
\end{tabular}

a) Numbers in bracket in this vertical column show those of municipalities covered in the surveys.

Phage resistant strains: Another distinct feature that has revealed in these surveys is that the incidence of phage resistant strains is unexpectedly low. Out of a grand total of 1256 isolates tested, only 17 (1.4 percent) were totally resistant to both $\mathrm{CP}_{1}$ and $\mathrm{CP}_{2}$. Relatively higher percentages were encountered in two individual series: one in the isolates from non-Satsuma sources in Ehime (8.1 percent) and the other in those from Satsuma sources in Wakayama (3.7 percent). These figures, however, should be interpreted as a result of the small numbers of specimens examined in these series rather than a direct indication for the actual presence in such ratios of resistant strains in these particular districts. Moreover, what is to be specifically emphasized here is the fact that the appearance of phage resistant strains was extremely casual and sporadic. There was no sign whatsoever of a possible localization of such strains in any part of a locality or of an orchard or even of a tree. In view of the scope of these surveys which is unsurpassed by earlier workers in Japan, there seems little possibility for the clustered distribution of resistant strains throughout the covered districts.

Intensive spot surveys Mode of distribution of $X$. citri strains: Results are given in Table 2. In Orchard A, 94 leaves were taken from three different portions of 9 individual Satsuma trees. Altogether, 1218 isolates were examined from a total of 216 canker lesions. Most of the isolates were $\mathrm{CP}_{2}$-sensitive while the rest was sensitive to both $\mathrm{CP}_{1}$ and $\mathrm{CP}_{2}$. That the dual sensitivity is 
Table 2. Mode of occurrence of Xanthomonas citri strains in intensive spot surveys

\begin{tabular}{|c|c|c|c|c|c|c|c|c|c|}
\hline \multirow{2}{*}{ Orcharda) } & \multirow{2}{*}{ Spot } & \multirow{2}{*}{ Tree $\left.^{b}\right)$} & \multirow{2}{*}{$\begin{array}{c}\text { Part of } \\
\text { tree } \\
\text { top }\end{array}$} & \multirow{2}{*}{$\begin{array}{l}\text { No. of } \\
\text { leaves }\end{array}$} & \multirow{2}{*}{$\begin{array}{l}\text { No. of } \\
\text { lesions }\end{array}$} & \multirow{2}{*}{$\begin{array}{l}\text { No. of } \\
\text { isolates }\end{array}$} & \multicolumn{3}{|c|}{ Phage sensitivity } \\
\hline & & & & & & & $\begin{array}{l}\mathrm{CP}_{1} \\
(+)\end{array}$ & $\begin{array}{l}\mathrm{CP}_{2} \\
(+)\end{array}$ & $\begin{array}{c}\mathrm{CP}_{1} \& \mathrm{CP}_{2} \\
(+)\end{array}$ \\
\hline \multirow{9}{*}{$\mathrm{A}$} & \multirow{3}{*}{ I } & U1 & $\mathrm{ABC}$ & 12 & 23 & 158 & 0 & 158 & 0 \\
\hline & & $\mathrm{U} 2$ & $\mathrm{ABC}$ & 10 & 24 & 134 & 0 & 134 & 0 \\
\hline & & U3 & $\mathrm{ABC}$ & 13 & 26 & 129 & 0 & 129 & 0 \\
\hline & \multirow{3}{*}{ III } & U1 & $\mathrm{ABC}$ & 11 & 21 & 116 & 0 & 116 & 0 \\
\hline & & U2 & $\mathrm{ABC}$ & 9 & 25 & 144 & 0 & 125 & $\left.19^{c}\right)$ \\
\hline & & U3 & $\mathrm{ABC}$ & 9 & 24 & 118 & 0 & 83 & $35^{\mathrm{d})}$ \\
\hline & \multirow{3}{*}{ III } & U1 & $\mathrm{ABC}$ & 9 & 25 & 137 & 0 & 137 & 0 \\
\hline & & U2 & $\mathrm{ABC}$ & 11 & 25 & 147 & 0 & 122 & $25^{\mathrm{e})}$ \\
\hline & & U3 & $\mathrm{ABC}$ & 10 & 23 & 135 & 0 & 135 & 0 \\
\hline \multirow[t]{8}{*}{ Total } & 3 & 9 & 27 & 94 & 216 & 1218 & 0 & 1139 & 79 \\
\hline & & U1 & A & 1 & 3 & 7 & 0 & 7 & 0 \\
\hline & $\mathrm{I}$ & $\mathrm{U} 2$ & A & 3 & 6 & 30 & 0 & 30 & 0 \\
\hline & & U3 & $\mathrm{AB}$ & 8 & 15 & 68 & 0 & 68 & 0 \\
\hline & & U4 & A & 4 & 5 & 18 & 0 & 18 & 0 \\
\hline & & U1 & $\mathrm{ABC}$ & 10 & 15 & 59 & 0 & 59 & 0 \\
\hline & II & U2 & $\mathrm{AB}$ & 6 & 16 & 79 & 0 & 79 & 0 \\
\hline & & U3 & $\mathrm{AB}$ & 6 & 15 & 57 & 0 & 57 & 0 \\
\hline \multirow[t]{9}{*}{ B } & III & U1 & A & 3 & 9 & 41 & 0 & 41 & 0 \\
\hline & & U2 & A & 3 & 8 & 30 & 0 & 30 & 0 \\
\hline & & I 1 & A & 3 & 9 & 40 & 0 & 40 & 0 \\
\hline & & I 2 & A & 3 & 7 & 35 & 35 & 0 & 0 \\
\hline & & I 3 & A & 4 & 9 & 45 & 45 & 0 & 0 \\
\hline & IV & I 4 & A & 3 & 9 & 45 & 45 & 0 & 0 \\
\hline & & I 5 & A & 3 & 9 & 44 & 0 & 44 & 0 \\
\hline & & N1 & A & 3 & 7 & 30 & 0 & 30 & 0 \\
\hline & & $\mathrm{N} 2$ & A & 3 & 8 & 61 & $20^{\mathrm{f})}$ & 41 & 0 \\
\hline \multirow[t]{4}{*}{ Total } & 4 & 16 & 21 & 66 & 149 & 689 & 145 & 544 & 0 \\
\hline & & N1 & A & 3 & 3 & 14 & 0 & 14 & 0 \\
\hline & I & N2 & A & 3 & 3 & 62 & 0 & 62 & 0 \\
\hline & & N3 & A & 4 & 6 & 48 & 0 & 48 & 0 \\
\hline \multirow{8}{*}{ C } & & N1 & A & 4 & 4 & 33 & 20g) & 13 & 0 \\
\hline & III & N2 & A & 3 & 3 & 48 & $8^{\text {h) }}$ & 40 & 0 \\
\hline & & N3 & A & 5 & 7 & 72 & $1^{\text {i) }}$ & 71 & 0 \\
\hline & & N1 & A & 3 & 3 & 51 & 0 & 51 & 0 \\
\hline & III & N2 & A & 3 & 3 & 45 & 0 & 45 & 0 \\
\hline & & N3 & A & 3 & 3 & 38 & 0 & 38 & 0 \\
\hline & IV & U1 & A & 3 & 3 & 58 & 0 & 58 & 0 \\
\hline & & U2 & A & 2 & 2 & 29 & 0 & 29 & 0 \\
\hline Total & 4 & 11 & 11 & 36 & 38 & 498 & 29 & 469 & 0 \\
\hline
\end{tabular}

a) Location of orchards, A: Tobe-cho, Iyo-gun, Ehime, B: Honai-cho, Nishiuwa-gun, Ehime, C : Doi-cho, Uma-gun, Ehime.

b) U: Satsuma orange, N : Natsudai orange, I : Iyokan orange.

c) Derived from 25 isolates which originated from 4 lesions on 2 leaves. One of 4 lesions consisted of two strains.

d) All isolates came from 6 lesions on 2 leaves. Each lesion was composed of one homologous strain.

e) Derived from 28 isolates which originated from 6 lesions on 4 leaves. Two of 6 lesions were composed of two strains.

f) One of 8 lesions produced two strains.

g), h), i) Derived respectively from one lesion solely occupied by one strain. 
intrinsic to the latter group was confirmed by the homologous reaction of a number of single cell progenies of a few representative isolates. These strains were detected, respectively, from 3 out of 9 trees, 5 out of 27 portions, 8 out of 94 leaves and 16 out of 216 lesions. They were found to occur singly on 5 leaves and together with $\mathrm{CP}_{2}$-sensitive strains on 3 leaves. Likewise, they were recovered singly from 13 out of 16 lesions and in mixture with $\mathrm{CP}_{2}$-sensitive strains from the rest of 3 lesions. Not without some exceptions, therefore, one can say that one single lesion of citrus canker is composed of one single strain of the causal bacteria. Distribution pattern in Orchard B were rather simple and well delimited. All Satsuma trees in Spot I, II, III had only $\mathrm{CP}_{2}$-sensitive strains while Iyokan and Natsudaidai trees in Spot IV produced either $\mathrm{CP}_{1}$-sensitive strains, $\mathrm{CP}_{2}$ sensitive strains or both strains. On one Natsudaidai tree that was concurrently infected with the two strains, 1 lesion was composed of both strains, all the rest of 7 lesions being made up of one strain which was either $\mathrm{CP}_{1}$-sensitive or $\mathrm{CP}_{2}$-sensitive. Orchard $\mathrm{C}$ was also characterized by the prevalence of $\mathrm{CP}_{2}$-sensitive strains. Only in Spot II was found a mixed presence of the two strains. All the individual lesions examined in this orchard consisted of one homologous strain.

Phage resistant strains: Unexpectedly enough, none out of a sum total of 2405 isolates examined in these spot surveys was resistant to both phages. Similar results were obtained in the surveys of the same design in Shizuoka prefecture where three widely separated plantings were selected. These data were not included in Table 2 because of the very poor recovery of the canker bacteria. Here again, none out of a total of 109 isolates was resistant to both phages. Such results may be partly due to inadvertent choice of orchards where only sensitive strains have been established. Nevertheless, when the findings from the foregoing wide range surveys are combined into account, the probability seems indeed scarce for the occurrence in clusters of resistant strains in our citrus districts.

First report on the lysing ability of phages $\mathrm{CP}_{1}$ and $\mathrm{CP}_{2}$ came from Wakimoto in 19676). $\mathrm{He}$ examined $40 \mathrm{X}$. citri isolates from scattered regions and found 1 resistant strain (2.5 percent). The numbers he dealt with were not only small but they contained only 13 isolates from Satsuma orange sources. In 1971, Serizawa ${ }^{5)}$ reported 16 (2.7 percent) resistant strains out of 602 which he gathered from 13 orchards in Shizuoka prefecture. A similar finding from more extensive covering of the same prefecture was presented by Obata et al. ${ }^{3)}$ in 1972 . They detected the presence of 7 (1.4 percent) resistant strains out of 483 strains tested. Another finding which may be qualitatively similar but which is quantitatively aberrant has been published more recently by Goto and Starr ${ }^{4}$. They reported that of a total of 87 cultures of $X$. citri which originated in Shizuoka prefecture, as many as 15 (20 percent) were resistant to all $X$. citri phages including $\mathrm{CP}_{1}$ and $\mathrm{CP}_{2}$. All the cultures tested by them were survivors from Dr. Goto's collections which dated back to 1962 or even older years. For as yet unknown reasons, phage sensitivity of $X$. citri often succumbs to varying degrees of modification during the growth on culture medium. The sensitivity to phage $\mathrm{CP}_{2}$ is particularly unstable. In many instances, it undergoes fatal deterioration which is hardly reversible by the conventional serial transfers. As they rightfully mentioned in their report, one possible explanation for the relatively higher rate of encounters with resistant strains in Goto-Starr's work is inadvertent selection of those strains that have lost sensitivity during a long spell of preservation. Conversely, the quantitative similarity of the findings of Serizawa's and of the author's might well have been derived from the use of newly harvested cultures in both cases.

In the light of the comprehensive covering of our major citrus export regions and also of a sizable number of isolates examined in the present surveys, it is concluded that the occurrence of resistant strains in natural conditions in Japan is indeed casual and rare. Circumstantial evidence 
also suggests for a possibility that even this rare emergence is incidental to a phenotypic status of the harvested cultures being tested. On the other hand, these findings also substantiate that the use of two phages $\mathrm{CP}_{1}$ and $\mathrm{CP}_{2}$ for the detection of citrus canker bacteria remains to be a reasonable as well as inevitable choice inasmuch as there are no other phages available for use in place of or in combination with these two. As far as the lysing ability is concerned, the divalent phage preparation consisting of $\mathrm{CP}_{1}$ and $\mathrm{CP}_{2}$ is effective for practically all $X$. citri strains that are known in major citrus districts in Japan.

\title{
Acknowledgements
}

This work was assisted by many colleagues of the author's. For the sake of direct contribution in part of this investigation, he feels obliged to honor the following persons in particular; Mr. M. Miyajima, Mr. K. Uehara, Mr. T. Noda, Mr. S. Morinaga, respectively, of Kobe Plant Protection Station, Mr. K. Kudō of Nagoya Plant Protection Station, and Mr. F. Tsuboi of Yokohama Plant Protection Station. Thanks are also due to Dr. S. Wakimoto, Kyushu University, for providing $\mathrm{CP}_{1}$ and $\mathrm{CP}_{2}$ phages and respective host bacteria and to Dr. T. Mizukami, National Institute of Agricultural Sciences, for going through the manuscript.

\section{Literature cited}

1. Adams, M. H. (1959). Bacteriophages. Interscience Publishers, New York. pp. 23-30.

2. Obata, T., Tsuboi, F. and Wakimoto, S. (1969). Res. Bull. Pl. Prot. Japan No. 7: 26-37.

3. Obata, T., Tsuboi, F., Kudo, K. and Imaizumi, T. (1972). Ann. Phytopath. Soc. Japan 38: 203 (abstr. in Japanese).

4. Goto, M. and Starr, M. P. (1972). Ann. Phytopath. Soc. Japan 38: 226-248.

5. Serizawa, S. (1971). Bull. Shizuoka Pref. Citrus. Exp. Sta. No. 9: 89-96. (Japanese with English summary).

6. Wakimoto, S. (1967). Ann. Phytopath. Soc. Japan 33: 301-310.

\section{和文摘要}

\author{
日本に分布する Xanthomonas citri の $\mathrm{CP}_{1}$ および \\ $\mathrm{CP}_{2}$ ファージ感受性 \\ 小畑 琢 志
}

輸出みかんの主要産地（アメリカ向けに設定されたかいよう病無病地区を除く）から多数のX. citri 菌株を 採集し, $\mathrm{CP}_{1}$ 㧊よび $\mathrm{CP}_{2}$ ファージに対する感受性からみた菌系の分布実態拈よび両ファージの溶菌範囲を検討 した。

静岡・和歌山・広島・徳島・愛媛各県の全域におよぶ採集の結果, 菌系の地域分布は, 広島県にのみ $\mathrm{CP}_{1}$ 感 受性菌系が多かった湾かは，いずれの県に扔いても $\mathrm{CP}_{2}$ 感受性菌系が優勢であった。しかし菌系の分布は品種に よって特徴があり, 温州には $\mathrm{CP}_{2}$ 感受性菌系が優位を占めるのに対し, 温州以外の品種から採集した菌株には両 菌系が種々の比率で険出された。 $\mathrm{CP}_{1}$ 感受性菌が広く分布する広島県にあっても, 温州単植園の多くは $\mathrm{CP}_{2}$ 感 受性の菌系が優勢であった。この調査において検定した計 1256 菌株のうち, 両ファージ耐性菌は 17 菌株 (1.4\%) であった。耐性菌の検出頻度は低いだけではなく, これが特定の地域や围場に局在して分布する兆候も認められ なかった。

菌系の微視的な所在様式を推定するため, 愛媛・静岡両県下に括いて数围場を選び, 局部的に多数の単個病 
斑から菌株の分離を括こなって調べた結果, 既知の菌系のほか, 両ファージのいずれにも感受性をもった菌系が 一部に検出された。ひとつの围場に複数の菌系が混在する場合, その混在は病葉レベルまではしばしば認められ るが,ひとつの病斑を構成する菌系は単一であることが多かった。この調査で検定した計 2514 菌株中には耐性 菌は存在しなかった。

以上の結果から $\mathrm{CP}_{1}$ 扎よび $\mathrm{CP}_{2}$ の両ファージを組合わせた溶菌範囲は, 日本の輸出みかん関係地域に分布 するX. citri の流とんど全部を包含するものと考える。 